\title{
MORPHOLOGY AND HISTOLOGY OF THE EURASIAN LYNX ( Lynx lynx) PLANUM NASALE
}

\author{
Hasan Hüseyin Ari $^{1,3}$, Sema Uslu ${ }^{2 *}$ \\ ${ }^{1}$ Departments of Anatomy, ${ }^{2}$ Departments of Histology and Embryology, Faculty of Veterinary Medicine, Sivas Cumhuriyet University, Sivas, \\ Turkey, ${ }^{3}$ Departments of Anatomy, Faculty of Veterinary Medicine, Kyrgyz-Turkish Manas University, Bishkek, Kyrgyzstan Republic
}

${ }^{*}$ Corresponding author, E-mail: semauslu43@hotmail.com

\begin{abstract}
This study reveals the macroscopic and microscopic structures of the Eurasian lynx planum nasale using materials from three dead females obtained from the Sivas Forestry Branch of Agriculture and Forestry Ministry of the Republic of Turkey. To accomplish the purpose, planum nasale was investigated using macroscopic, histological, and scanning electron microscopy (SEM) techniques. The microscopic examination showed that the planum nasale consists of hairless, moist, glabrous skin and resembles a ship anchor with arm, palm, stock, and sickle parts. The planum nasale's surface is formed by epidermal plates or epidermal ridges, which were separated from each other by primary and secondary fissures showed in SEM and macroscopic figures. Based on the microscopic examination, the Mercel's cells and nerve ends are located in the basal sheet of the planum nasale's epidermal layers. In addition, the pores situated on the surface of the epidermal ridges and the dense connective bundles were settled in the dermal layers, based on the SEM examination.
\end{abstract}

Key words: Eurasian lynx (Lynx rufus); morphology; nasal plane; planum nasale

\section{Introduction}

The Euroasian lynx (Lynx lynx) is an endangered species of wild animal (1). The species features of the lynx are medium size, a small head, a prominent ruff of fur, ears tipped with tufts of black hair, and long legs relative to its body length. The literature reports that the most distinguishing anatomical characteristic of these wild animals is the absence of a set upper premolar (2).

The planum nasale, which comes from a Latin word meaning the tip of the nose, is a well-studied anatomical and histological structure in various

Received: 5 July 2020

Accepted for publication: 12 November 2021 species $(3,4,5,6,7)$. This anatomical structure is called the nasal plane (planum nasale) in carnivores and small ruminants but the nasolabial plane (planum nasolabiale) in large ruminants and the rostral plane (planum rostrale) in swine. The nasal plane is macroanatomically formed by glabrous skin and philtrum, different from other regions of the head $(8,9,10,11)$. The skin of the nasal plane includes medial nasal wings, which are differentiated for adaptation to different environments. The surface of the nasal plane skin exhibits a unique morphology that includes papillae or epidermal ridges $(4,5)$. The anatomical structure consists of the epidermal ridges, which are used as a nasal print $(5,12)$ because of the individual animal's characteristics throughout 
life $(13,14)$. Histologically, the planum nasale's skin consists of an epidermis and a dermis. In addition, Esrah (5) reported that skeleton muscle exists just below the dermis.

The morphology of the planum nasale has been compared between various species for many years. Despite several current studies on the anatomical structures of the Eurasian lynx $(1,15)$, to our knowledge, no anatomical descriptions of the nasal plane in the Eurasian lynx are available, so this study could present the first anatomical findings on the planum nasale obtained using light and scanning electron microscopy.

\section{Materials and methods}

\section{Gross anatomy}

The three female Eurasian lynx used in this study died from natural causes (cadaver I was $6,9 \mathrm{~kg}$, cadaver II was 7,6 and cadaver III was $7,2 \mathrm{~kg}$ in weight, respectively). The animals were obtained from the Republic of Turkey Ministry of Agriculture and Forestry (Sivas branch) and were immediately transported to the Anatomy Department of the Veterinary Faculty of Sivas Cumhuriyet University (16). Then, we bilaterally inserted a plastic cannula into their common carotid artery and cleaned the arterial system of each cadaver with hydrogen peroxide and water solution. We fixed the cadavers with a $10 \%$ formalin solution administered via the plastic cannula. The planum nasale of each cadaver was photographed with a Canon EOS 50D camera. The nomenclature used in this study was adopted from the Nomina Anatomica Veterinaria (17).

\section{Light microscopy}

The tissue samples were fixed in buffered formalin for $24 \mathrm{hr}$, dehydrated in graded alcohol, and embedded in paraplast to create blocks. Serial sections were cut at 5-6 $\mu \mathrm{m}$ thickness. The sections were stained with a modified version of Mallory's triple stain for general histological examination (18).

\section{Scanning electron microscopy}

The specimens collected from the planum nasale samples were washed in distilled water and $2.5 \%$ glutaraldehyde three times (10 $\mathrm{min}$ each), dehydrated in an ascending series of ethyl alcohol solutions $(50 \%, 70 \%, 90 \%$, and $100 \%$ alcohol), dried until they reached the critical point using liquid carbon dioxide, and mounted on metal stubs. The samples were coated with a goldpalladium alloy using a sputtering device; then, we examined and photographed the specimens with a scanning electron microscope (Zeiss, Germany) $(10 \mathrm{kV})$ at the Advanced Technology Research Centre of Sivas Cumhuriyet University, Sivas (19).

Ethical Statement: This study was approved by the Republic of Turkey Ministry of Agriculture and Forestry (Sivas branch) (09.08.2018-72784983488.04-176382).

\section{Results}

\section{Gross morphology}

The planum nasale of the Eurasian lynx is located around the two nostrils and the middle area of the upper lip. Its skin surface is hairless, glabrous, moist, and grayish-black, and it has a dermatoglyphic pattern consisting of epidermal ridges (see Figure 1). It was divided by a philtrum into two equal halves, around the nostril and only the middle area of the upper lip (see Figure 1). The planum nasale of Eurasian lynx was in the form of a sketchy ship anchor shape consisting of arm, palm, shank, stock, and shackle parts (see Figure 1A). The arm of the ship anchor was directed to the dorsum nasi, while the shank was directed toward the ventral of the planum nasale. The arm of the planum nasale (the arrow in Figure 1A) is located dorsally to the tip of the nose, while its palm ("Pa" in Figure 1A) is situated at the dorsolateral wings of the nose, directed medioventrally. A black dorsal border (the arrow in Figure 1A) was evident between the hairy skin of the dorsum nasi and the arm of the planum nasale. The dorsal border of the planum nasale's arm was concavely directed toward the dorsum nasi. The width of the planum nasale arm dorsally supported the nostril ("Ns" in Figure 1A) and was wider than the planum nasale's palm. The planum nasale's palm ("Pa" in Figure 1A) on both sides situated the lateral wings of the nose and the dorsolateral of the planum nasale. The width of the planum nasale's arm dorsally surrounding the nostril was wider than the planum nasale's 


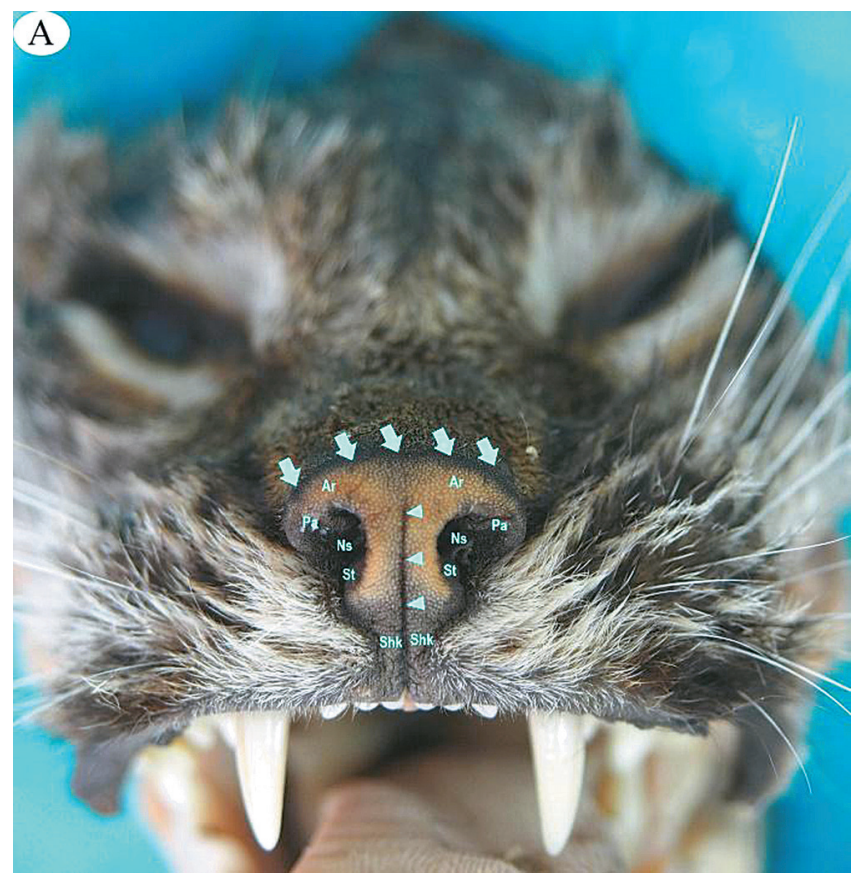

Figure 1A: The macroscopic view of Eurasian lynx Planum nasale. (A) A photograph of the planum nasale's anatomical structures: the arm $(\mathrm{Ar})$, palm $(\mathrm{Pa})$, and dorsal border of the planum nasale (arrow); the nostril (Ns); the philtrum (arrowhead); the shank (Sh); and the shackle (Shk) and stock of the planum nasale (St)

palm. The planum nasale palm on either side was situated around the lateral wings of the nose and dorsolateral limited the nostrils. The lateral border of the convex planum nasale palm firstly began from the dorsal side of the nostril, then continued to the medial side, and finally ended at the ventral side. The lateral and dorsal borders of the planum nasale and philtrum (arrowhead in Figure 1A) were dark-colored glabrous skin, unlike the arm, which comprises glabrous light-colored skin in the central portion planum nasale's arm. The planum nasale's shank ("Sh" in Figure 1A) is situated in the area between the left and right nostrils. The philtrum (the arrowhead in Figure 1A) extended from the dorsal midline of the planum nasale's shank to the planum nasale's shackle and upper lip. The planum nasale's stock ("St" in Figure 1A) is located mediolaterally in the ventral portion of the planum nasale, and the ventral part of the planum nasale shank narrows dorsally to the upper lip to become the shackle of the planum nasale ("Shk" in Figure 1A). The skin of the planum nasale's shackle and the upper lip was dark and is divided into two equal halves by the philtrum. The glabrous skin surfaces of the planum nasale have many moist dermal protuberances and grooves

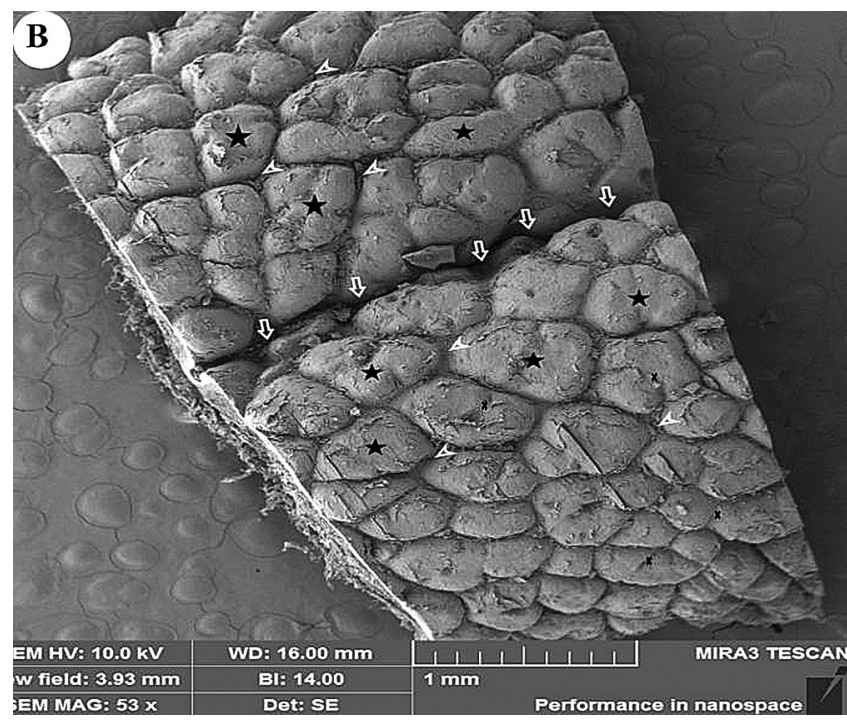

Figure 1B: An SEM image of a planum nasale's surface, with the epidermal ridges (stars), shallow fissures (arrowhead), secondary fissures (the mark), and small pores (stars).

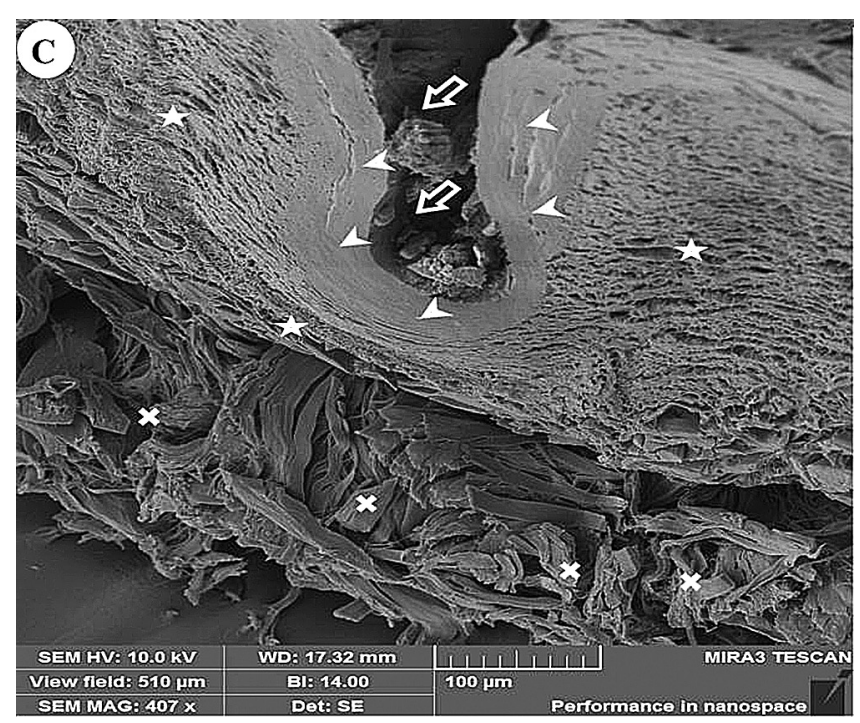

Figure 1C: An SEM image of a planum nasale's surface and section, with a profound groove (arrows), the epidermis (arrowheads), the dermis (star), and connective bundles (X mark)

(the star in Figure 1A), which were wider and darker in the central area of the planum nasale than at the edges of the planum nasale.

Histological Examination: The glabrous skin of planum nasale in the Eurasian lynx histologically consisted of the epidermis (Figure 2A) and dermis (Figure 2A) layers. Deep indentations (Dermal papillae) were seen (Figure 2B) between the epidermis and dermal layers. The epidermis, formed by the hairless keratinized squamous 

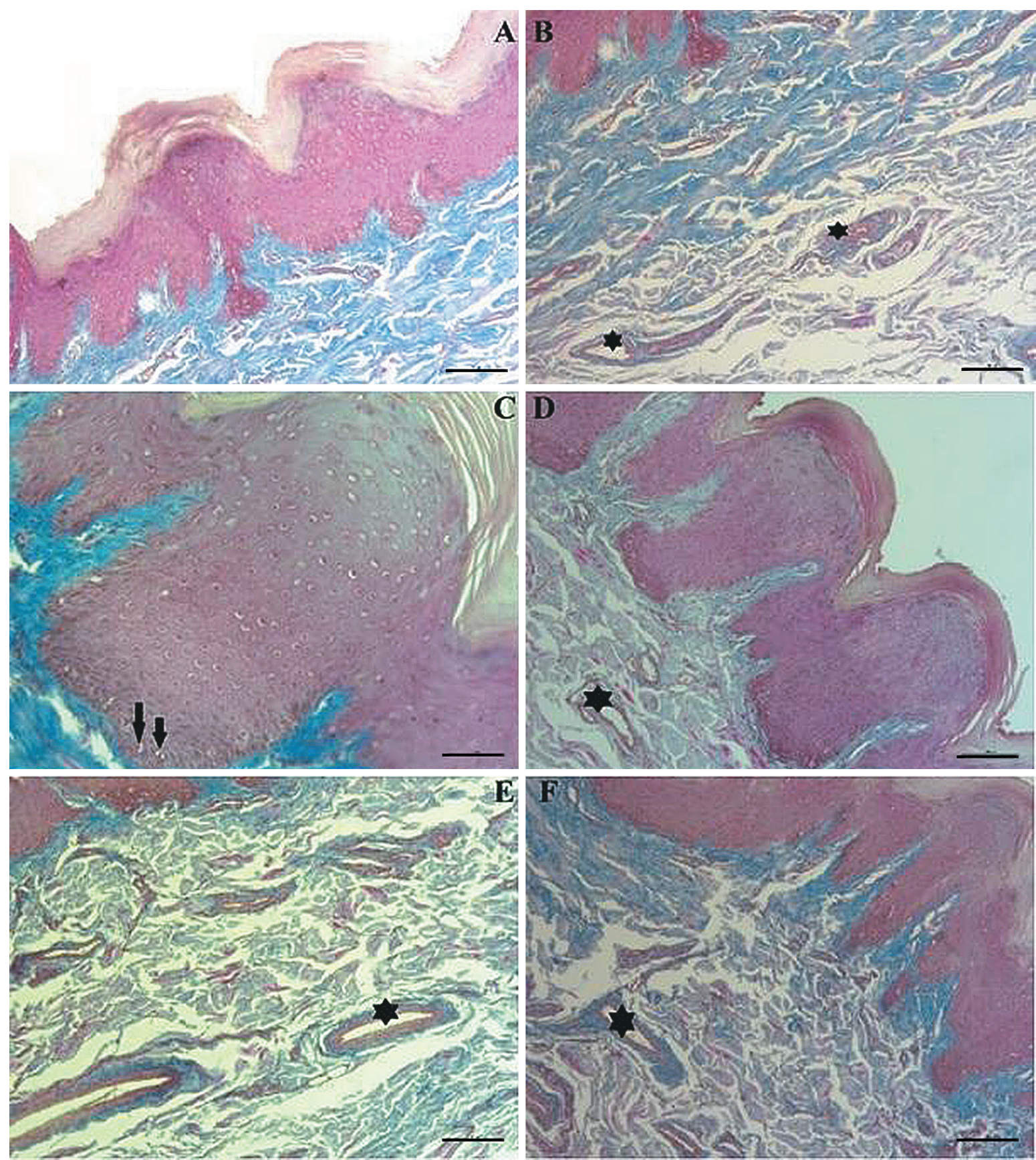

Figure 2: The histological view of Eurasian lynx planum nasale

epithelium, was composed of the basal, spinous, granular, lucid, and corneum strata in the histological preparations stained with triple stain. In the samples, the basal stratum was formed by single layers of cells located on the basement membrane (arrow in Figure 2C). The mechanoreceptor cells were seen in the basal layer. These cells were thought to have endings in the immediate vicinity (in Figure 2C). The granular layer was composed of two to three cell rows, while the spinous layer consisted of three to five polyhedral cell rows (mark in Figure 2C). The stratum corneum was the most superficial on the epidermis; it is thin and has multiple layers of ceratinocytes. The boundaries of the dermis layer, which has deep and superficial layers, were not evident in the triple-stained preparations. Deep in the dermis were more connective fibers than in the superficial areas. In addition, abundant veins and venules were situated (star in Figure 2D-F) in the dermis layer. 


\section{Scanning electron microscopy examination}

The SEM surface examination showed many differently sized epidermal ridges in the samples (the stars in Figure 1B), separated from one another by shallow fissures (the arrowheads in Figure 1B). The epidermal ridges were divided into more small domes by secondary fissures (the mark in Figure 1B). The shapes of the epidermal ridges differ from each other, both among samples and between the halves of the same animal specimens. Small pores were situated in the middle of the epidermal ridges (the plus in Figure 1B). The philtrum was a profound groove in the middle line of the samples (the arrows in Figure 1B). The SEM depth module examination of the samples showed that both the philtrum and skin epidermal ridges were composed of epidermal layers (the arrowheads in Figure 1C) and that the dermal layers included dense connective bundles with different sizes and directions (the star and $\mathrm{X}$ mark in Figure 1C).

\section{Discussion}

The unique anatomical structures of the skin, such as the planum nasale, form through skin differentiation in various regions. The region, as previously described in ruminants $(5,7)$ and lemurs (3), is an extensive and easily distinguishable patch of moist, glabrous skin around the nostrils in the Eurasian lynx. In addition, the species' planum nasale has a dark border on the dorsal, lateral, and ventral sides.

On close macroscopic inspection, the planum nasale surface of the Eurasian lynx appears to be composed of packed polygonal plates or epidermal ridges, fissures, and a philtrum, as depicted in carnivores $(8,9)$, camels $(5)$, and lemurs (3). In addition, the shape of the Eurasian lynx's planum nasale resembles a ship anchor consisting of arm, palm, shank, stock, and shackle parts. The arm and palm are situated dorsally to the nostrils, while the shank and stock parts are located medially and ventrally, respectively, to the nostrils in the Euroasian lynx. As previously described in ruminants $(5,6,7,20)$ and lemurs (3), the philtrum also divides the planum nasale into two halves in the Eurasian lynx. Moreover, as shown by the gross and SEM samples, in the Eurasian lynx, it has been seen that the philtrum continues to the middle of the upper lip and divides the upper lip.

In the macroscopic and SEM examinations, we found that the shapes of the epidermal ridges differ between the planum nasale halves from the same individual and among the planum nasale of different individuals. The findings are similar to descriptions reported of primates by Clifford and Witmer (12) and of cattle by Solis and Maala (14). As described by literature $(12,14)$, the different shapes of the planum nasale's skin plates may be used for individual identification of the animals as nose prints. In addition, we observed that the pores are situated on some skin plates. The skin plate is split into multiple secondary skin plates with shallow grooves. We observed that the shapes of the skin plates differed from of camels those photographed with SEM microscopy (5).

In agreement with findings from the literature $(3,5)$, we observed that the histological structure of the planum nasale's skin consisted of the epidermis and dermal layers. However, the hypodermal layer could not be seen in this study. As reported in the literature $(3,5)$, a wavy border was seen between the epidermis and dermal layers because of the evident epidermis and dermal papillae in the histological samples. In this study, we saw that the basal sheet of the epidermal layer was formed by a single cell layer, as depicted in Lemur catta (3) and camels (5), whereas our findings of Mercel's cells in the sheets were only similar to the description by Elofsson et al. (3) in Lemur catta. In addition, as reported by previous studies $(3,5)$, we observed that the granular sheet was thinner than the spinous sheet. The superficial stratum corneum of the planum nasale in the Eurasian lynx is the same as that of camels (5) and Lemur catta (3), in terms of thickness.

Our findings, such as dense connective fibers, rich blood vessels, and dermal papillae in the dermal layers, resemble the statements by Eshrah (5) in camels and Elofsson et al. (3) in Lemur catta.

\section{Conclusion}

The nasal plane or planum nasale of the Eurasian lynx was investigated. In this study, we observed that the Eurasian lynx's planum nasale consists of glabrous, moist, and hairless skin around nostrils and that its gross morphological shape is in the shape of a ship anchor consisting 
of arm, palm, shank, stock, and shackle parts. Both the morphological and SEM investigations show that the planum nasale's skin is divided by primary and secondary fissures and splinted into epidermal ridges with different sizes and shapes. The different surface shapes of the epidermal ridges in the Eurasian lynx are used for individual identification by nose print, as in other animals. In the histological examination, we saw that the planum nasale's skin is composed of dermis and epidermal layers. The unmyelinated nerve endings located on the basal sheet of the epidermal layers may be evidence of a sensitive structure. In the SEM examination, we saw small pores on the epidermal ridges and dense bundles in the dermal layers. The dense bundles may create resistance against mechanical effects.

\section{Acknowledgments}

We would like to thank the Republic of Turkey Ministry of Forestry (Sivas Branch) for permission to conduct studies on the Eurasian lynx (Lynx lynx).

This study was not supported by any foundation.

The authors declare that they have no conflict of interest. Statement of Animal Rights all applicable international, national, and/or institutional guidelines for the care and use of animals were followed.

\section{References}

1. Ozgel O, Aykut M. Macro anatomical investigation on ossa membri pelvini of Anatolian bobcat Lynx. Pakistan J Zool 2015; 47: 1492-4.

2. Hansen K. Bobcat: master of survival. Oxford : University Press, 2007.

3. Elofsson R, Tuminaite I, Kröger RHH. A complex sensory organ in the nose skin of the promisisian primate Lemur catta. J Morphol 2015; 276: 649-76. doi: 10.1002/jmor.20363

4. Elofsson R, Tuminaite I, Kröger RHH. A novel ultrastructure on cornicocyte surface of mammalian nasolabial skin. J Mammal 2016; 95: 1288-94. doi: 10.1093/jmammal/gyw112.

5. Eshrah EA. The camel rhinarium: a study revealing the presence of the nasal plane in the dromedary camel (Camelus dromedarius) with special reference to its epidermal structure. Anat Histol Embryol 2017; 46: 65-72. doi: 10.1111/ahe.12238
6. Maya S, Chungath JJ, Ashok N, Lucy KM, Sreeranjini AR, Indu VR. Comparative morpho-histology of muzzle in deer and goat. J Indian Vet Assoc 2015 ; 12: 46-9.

7. Kalita HC, Kalita PC. Comparative gross anatomical studies on the muzzle of the mithun (Bos frontalis), yak (Bos grunniens) and zebu (Bos indicus). Indian J Anim Res 2004; 38: 150-2.

8. Dyce KM, Sack WO, Wensing CJG. Textbook of veterinary anatomy. Saunders. 1996.

9. Getty R. Sisson and Grossman's the anatomy of the domestic animals. WB Saunders. 1975.

10. König HE, Liebich HG. Veterinary anatomy of domestic mammals: Textbook and colour atlas. Schattuer. 2004.

11. Nickel R, Schummer A, Seiferle E. The viscera of the domestic animals. Verlag Paul Parey. 1973.

12. Clifford AB, Witmer LM. Case study in novel narial anatomy: The enigmatic nose of moose (Artiodactyla: Cervidae Alces alces). Journal of Zoology 2004; 262: 339-60. doi: 10.1017/ S0952836903004692

13. Kozma SM. Feasibility of animal nose print identification using two-dimensional image correlation [Unpublished master's dissertation]. San Diego University, 2004.

14. Solis JA, Maala CP. Muzzle printing as a method for identification of cattle and carboas. Philippine Journal of Medicine 1975; 14: 1-4

15. Ar1 HH, Kuru N, Uslu S, Özdemir Ö. Morphological and histological study on the foot pads of the Anatolian bobcats (Lynx lynx). The Anatomical Record, 2018; 301: 932-8. doi: 10.1002/ar.23761

16. Anonymous. Cumhuriyet University was delivered dead Lynx in Sivas in order to make the post-mortem examination. 2016. www.sivas.ormansu.gov.tr/sivas/Anasayfa/resimliHaber.

17. International Committee on Veterinary Gross Anatomical Nomenclature. Nomina Anatomica Veterinaria. 2012.

18. Bancroft JD. Cook HC. Manual of histological techniques. Livingstone, 1984.

19. Mahdy MAA, Abdalla KEH, Mohamed SA. Morphological study of the hard palate in the Egyptian goat (Capra hircus): A scanning electron microscopic study. Anatomia, Histologia, Embryologia, 2018; 47: 391-397. doi: 10.1111/ahe12366

20. Metwally MA, Huissieni HB, Kassab AA, Eshrah EA. Comparative anatomy of the nasal cavity in the buffaloes, camels and donkeys. Journal of Veterinary Medicine Research 2019; 9: 69-75. 


\title{
MORFOLOGIJA IN HISTOLOGIJA SMRČKA EVRAZIJSKEGA RISA (Lynx lynx)
}

\author{
H. H. Ari, S. Uslu
}

Izvleček: V študiji so opisane makroskopske in mikroskopske strukture smrčka evrazijskega risa, ki je bila opravljena s proučevanjem tkiv treh mrtvih samic, ki so jih pridobilis pomočjo gozdarske podružnice Sivas Ministrstva za kmetijstvo in gozdarstvo Republike Turčije. Strukturo smrčka so raziskovalizuporabo makroskopskih, histoloških metod teruporabevrstičnega elektronskega mikroskopa (SEM). Mikroskopska preiskava je pokazala, da smrček sestavlja brezdlaka, vlažna, gola koža, ki po obliki spominja na ladijsko sidro. Površinski del smrčka tvorijo epidermalne plošče ali grebeni, ki jih ločujejo primarne in sekundarne razpoke, vidne na makroskopskih slikah in s pomočjo vrstične mikroskopije. Na histoloških preparatih so bile v bazalni plasti smrčka epidermisa opazne Merkelove celice in živčni končiči. S pomočjo metode SEM so v plasti epidermisa pokazali pore, ki se nahajajo na površini epidermalnih grebenov in snope togega fibrilarnega veziva, ki segajo v plast dermisa.

Ključne besede: Evrazijskiris (Lynx rufus); morfologija; nosna ravnina; smrček 